\title{
Isolation and Identification of Endophytic Bacteria with Plant Growth Promoting Activity and Biocontrol Potential from Wild Pistachio Trees
}

\author{
Faegheh Etminani and Behrouz Harighi (1)* \\ Department of Plant Protection, Faculty of Agriculture, University of Kurdistan, Sanandaj, Iran \\ (Received on July 22, 2017; Revised on February 18, 2018; Accepted on February 26, 2018)
}

In this study, samples were collected from the leaves and stems of healthy wild Pistachio trees (Pistacia atlantica L.) from various locations of Baneh and Marivan regions, Iran. In total, 61 endophytic bacteria were isolated and grouped according to phenotypic properties. Ten selected isolates from each group were further identified by partial sequencing of the 16S rRNA gene. Based on the results, isolates were identified as bacteria belonging to Pseudomonas, Stenotrophomonas, Bacillus, Pantoea and Serratia genus. The ability of these isolates was evaluated to phytohormone production such as auxin and gibberellin, siderophore production, phosphate solubilization, atmospheric nitrogen fixation, protease and hydrogen cyanide production. All strains were able to produce the plant growth hormone auxin and gibberellin in different amounts. The majority of strains were able to solubilize phosphate. The results of atmospheric nitrogen fixation ability, protease and siderophore production were varied among strains. Only Ba66 could produce a low amount of hydrogen cyanide. The results of biocontrol assay showed that $\mathrm{Pb} 78$ and Sp15 strains had the highest and lowest inhibition effects on bacterial plant pathogens, Pseudomonas syringae pv. syringae Pss20 and Pseudomonas tolaasii Pt18 under in vitro condition. Pb3, Pb24 and Pb71 strains significantly promote root formation on carrot slices. To our knowledge this is the first report of the isolation

*Corresponding author.

Phone)+98-87-33620552, FAX) +98-87-33620553

E-mail)bharighi@uok.ac.ir

ORCID

http://orcid.org/0000-0003-4776-8933

(c) This is an Open Access article distributed under the terms of the Creative Commons Attribution Non-Commercial License (http:// creativecommons.org/licenses/by-nc/4.0) which permits unrestricted noncommercial use, distribution, and reproduction in any medium, provided the original work is properly cited.

Articles can be freely viewed online at www.ppjonline.org. of endophytic bacterial strains belonging to Pantoea, Bacillus, Pseudomonas, Serratia and Stenotrophomonas genus from wild pistachio trees with plant growth promoting potential and biocontrol activity.

Keywords: Bacillus, endophytic bacteria, plant growth promotion, Pseudomonas, Stenotrophomonas, wild pistachio tree

Handling Associate Editor : Sang, Mee Kyung

Plants are naturally associated with diverse microorganisms in various ways. One group of these microorganisms, endophytic bacteria, can colonize internal tissues of host plant, including aboveground and underground parts and seeds without damaging host cells (Reinhold-Hurek and Hurek, 2011). Bacteria reported as endophytes include a significant range of both Gram-positive and -negative bacteria belonging to genera of Alpha-, Beta- and Gammaproteobacteria, as well as Actinobacteria and Firmicutes (Bacon and Hinton, 2006). Although research regarding endophytic bacteria is still overlooked, it is one of the most promising aspects of microbiological studies. Endophytic bacteria promote plant growth, possess the capacity to solubilize phosphate and contribute assimilable nitrogen to plants (Rosenblueth and Martinez-Romero, 2006). Furthermore, their plant growth-promoting activity may be due to the production of phytohormones and/or enzymes involved in growth regulator metabolism (Taghavi et al., 2009). These bacteria colonize the same ecological niche in plants as plant pathogens and have widely recognized mechanisms of biocontrol activity such as competition for ecological niche or substrate, production of inhibitory chemicals and induced systemic resistance in the host plants against a broad spectrum of pathogens (Compant et al., 2005). In addition, the interactions between plants and endophytic bacteria might help plants to settle in ecosystem restoration 
processes. Each plant species might be a host for one or more endophytic bacterial species. Presence of endophytic bacterial species and their population density is highly variable depending on the bacterial species, host genotypes and environmental conditions (Chebotar et al., 2015).

Although the majority of research has focused on endophytic bacteria associated with important agricultural plants because of their positive effects on the host trees, finding useful strains for forest practices might have plant growth promotion effects and improve environmental quality. It is possible that microorganisms associated with forest trees enhance host survival under harsh environmental situations. Among various microorganisms associated with forest trees, less is known about the role and diversity of their bacterial counterparts. There is little research on endophytic bacteria-forest trees interaction. Some studies have shown that the genetic background of plant hosts had direct influence on endophytic bacterial community structure (Ulrich et al., 2007). The most common genera of endophytic bacterial community isolated from forest trees include Pseudomonas, Bacillus, Acinetobacter, Actinobacteria, Sphingomonas and some genera belong to the Enterobacteriacae family (Pirttila and Frank, 2011). Taghavi et al. (2009) reported an Enterobacter sp. strain with ability to enhance the growth of poplar cutting. Diazotrophic endophyte strains were isolated from Populus trichocarpa and Salix sitchensis trees (Doty et al., 2009). Lodgepole pine harbor endophytic bacteria, Paenibacillus polymyxa with the ability to fix nitrogen (Anand et al., 2013) and Enterobacter cloacae strains which could produce indole acetic acid under in vitro condition were isolated from Mediterranean pines (Madmony et al., 2005).

As the plant growth promoting properties of endophytic bacteria might vary, it is important to investigate such properties of bacterial populations associated with economically important forest trees. Pistacia genus belongs to the Anacardiaceae family, Pistacia atlantica subsp. kurdica and $P$. atlantica subsp. mutica, are the most important subspecies of wild pistachio trees growing in the Zagros forest of north-west and western part of Iran (Mozaffarian, 1998). Useful products such as resin derived from various parts of tree have high economicvalue. Wild pistachio trees have widespread distribution, survive and grow well under extreme environmental conditions. Despite the ecological and economic importance of wild Pistachio, no studies are found on endophytic bacteria associated with this plant and its possible role in bacteria-plant host interaction. The aims of the present study were: (i) isolation and identification of endophytic bacteria associated with wild pistachio trees from various locations of Kurdistan province, Iran, (ii) the screening of isolates for a number of plant-growth promotion potential, and (iii) evaluation of biological control potential of isolates against some bacterial pathogens under in vitro condition.

\section{Materials and Methods}

Sample collection, Isolation and characterization of endophytic bacteria. Leaf and stem samples were collected from healthy wild pistachio trees (Pistacia atlantica subsp. kurdica) growing in the Zagros mountains of Kurdistan province between June and July 2014 and 2015. The sampling locations included Sarvabad ( $\left.35^{\circ} 30^{\prime} \mathrm{N}, 46^{\circ} 35^{\prime} \mathrm{E}\right)$,

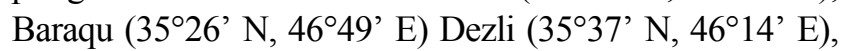

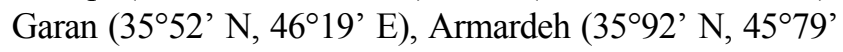
E), Balakeh ( $35^{\circ} 84^{\prime} \mathrm{N}, 45^{\circ} 77^{\prime}$ E) and Parsheh (36 $12^{\circ} \mathrm{N}$, $45^{\circ} 71^{\prime}$ E). Small pieces of samples were washed with tap water, sterilized with $5 \%$ sodium hypochlorite for $5 \mathrm{~min}$ followed by washing 4-5 times with sterile-distilled water. $50 \mu$ of the final wash was spread onto nutrient agar medium as a control. After that, the sterilized pieces were macerated in $5 \mathrm{ml}$ of sterile distilled water for $30 \mathrm{~min}$ and $50 \mu \mathrm{l}$ of final suspension was cultured onto nutrient agar, nutrient agar plus 5\% sucrose, King B agar and LB agar media. All plates, including control were incubated at $26-28^{\circ} \mathrm{C}$ for 14 days and observed daily. Morphologically distinct colonies were selected, purified on the same medium and used for further studies. Bacterial isolates were tested for catalase and oxidase activity, gram reaction and the production of fluorescent pigment on King B agar according to methods previously described (Schaad et al., 2001).

Amplification and sequencing of the 16S rRNA gene. Bacterial isolates were grown in nutrient broth medium for $24 \mathrm{~h}$ at $28^{\circ} \mathrm{C}$ and genomic DNA was extracted using phenol/chloroform procedure as previously described (Kheirandish and Harighi, 2015). Amplification of the 16S rRNA gene was performed with the universal primer pairs of fD2 (5'-AGA GTT TGA TCA TGG CTC AG-3', position 8-27) and rP1 [5'-ACG GTT ACC TTG TTA CGA CTT-3', position 1512-1492 (Escherichia coli)] (Weisburg et al., 1991). The PCR products were sequenced using an ABI3730XL DNA sequencer (Foster city, CA, USA). 16S rRNA gene sequences obtained was first aligned by using Ibis Therapeutics (Carlsbad, CA, USA) (Hall, 1999). Then, the sequences obtained were further aligned to other closely related bacterial species deposited in NCBI database using the BlastN program. The phylogenetic tree was constructed for bacterial isolates along with the sequences from selected references strains. The analysis was conduct- 
ed with PAUP v. $4.0 \mathrm{~b} 10$ (Swofford, 2003) using neighborjoining method (Bootstrap analysis with 1000 replicates).

Biocontrol activity of endophytic bacteria. Two bacterial plant pathogens, $P$. syringae pv. syringae strain Pss 20 (GeneBank accession numbers KX160011, KX160031, KX160051 and KX160071) and P. tolaasii strain Pt18 (GeneBank accession number KY203807) previously identified as a broad- and narrow-host range bacteria respectively were chosen as indicators. $300 \mu 1$ suspension of bacterial pathogen (approximately $2 \times 10^{8} \mathrm{cfu} / \mathrm{ml}$ ) was poured into the plates containing nutrient agar and kept at room temperature for $5 \mathrm{~min}$. Then, sterile paper discs preimmersed in suspension of endophytic bacteria (concentration of about $10^{8} \mathrm{cfu} / \mathrm{ml}$ ) were spotted on the pathogeninoculated plates. Plates were incubated at $28^{\circ} \mathrm{C}$ for $48-72 \mathrm{~h}$ and the width of the inhibition zones was measured. Sterile water spotted in the plates with the pathogen was used as a control (Aliye et al., 2008). The experiment was repeated twice with four replications.

Plant growth-promoting potential of endophytic bacteria. All isolates were evaluated for their plant growth promotion properties. Solubilization of phosphate on Pikovskaya agar medium, siderophore production on CAS medium, ability to fix nitrogen on nitrogen-free $\mathrm{NFb}$ medium and HCN production were assessed using methods previously described by Naik et al. (2008), Schwyn and Neilands (1987) and Döbereiner et al. (1995), respectively. Isolates were assessed for the hydrogen cyanide (HCN) production by using method of Alstrom and Burns (1989). $50 \mu 1$ of each bacterial suspension was streaked onto nutrient agar medium with whatman paper soaked in picric acid solution placed inside the lids. The plates were sealed with parafilm and incubated in an inverted position at $26-28^{\circ} \mathrm{C}$ for 7 days. Color change of paper to orange or red indicated $\mathrm{HCN}$ production.

Protease production was determined according to the method previously described (Sgroy et al., 2009) with some modifications. Plates containing skim milk agar (SMA) medium ( $\mathrm{g} / \mathrm{l}$ of distilled water: pancreatic digest of casein, 5; yeast extract, 2.5; glucose, $1 ; 7 \%$ skim milk and agar, 15 ) were inoculated with $10 \mu \mathrm{l}$ of bacterial isolates, incubated at $28^{\circ} \mathrm{C}$ for up to 4 days and observed for the formation of the halo zone around the colonies.

Indole acetic acid (IAA) and gibberellic acid (GA) production. Endophytic bacterial isolates were inoculated into nutrient broth media containing $0.2 \%(\mathrm{v} / \mathrm{v})$ L-tryptophan and incubated at $28^{\circ} \mathrm{C}$ for 10 days with vigorous shaking. then, IAA production was calculated according to the procedure described by Rahman et al (2010). A standard curve of various concentrations of pure IAA (Merck, Frankfurt, Germany) in the range of $0-250 \mu \mathrm{g} / \mathrm{ml}$ was prepared by plotting IAA concentration to optical density (at $530 \mathrm{~nm}$ ). Then, the concentration of IAA produced by each isolate was determined by using this standard curve according to the following equation: $\mathrm{Y}=0.0071 \mathrm{X}+0.1108, \mathrm{R}^{2}=1$. Production of gibberellic acid by isolates was determined using the method of Holbrook et al (1961). Concentration of GA produced by each isolate was calculated using GA standard curve with the equation of: $\mathrm{Y}=0.00005 \mathrm{X}^{2}+$ $0.0263 X-0.3132$. Both experiments were repeated three times.

Effect of endophytic bacteria on root formation. An experiment was carried out to test if endophytic bacteria can induce root formation. Small pieces of carrot with the same size were prepared, surface sterilized by submerging in $70 \%$ ethanol for $3 \mathrm{~min}$, rinsing 3 times with sterile-distilled water, and subsequently treated with $0.5 \% \mathrm{NaClO}$ for 7 min. Finally, the samples were washed in sterile-distilled water three times. Samples were transferred to sterile tubes containing $5 \mathrm{ml}$ MS growth media and $80 \mu \mathrm{l}$ of the endophytic bacteria $\left(\mathrm{OD}_{600} \simeq 0.5\right)$ was added. The tubes were incubated at $25^{\circ} \mathrm{C}$ for four weeks with a $16 \mathrm{~h}$ photoperiod. Observations were recorded on wet weight of the roots. Cutting samples placed in tubes containing media without endophytic bacteria were used as control. The experiment was set out as a completely randomized design with three replications.

Statistical analysis. Data analysis was performed using the SAS institute (NC, USA) and comparison of means was made with LSD test at the $1 \%$ level. Graphs were plotted with Excel software (Microsoft, WA, USA).

\section{Results}

Identification of endophytic bacterial isolates. Results obtained in this study revealed that wild Pistachio trees harbor an abundance of culturable endophytic bacteria. Sixtyone endophytic bacteria were isolated from the leaves and stems. The absence of bacterial colony on control plates confirmed that isolates obtained are endophyte. All isolates were tested for a number of important properties (Table 1). $20 \%$ and $80 \%$ of isolates were Gram-positive and -negative, respectively. Based on the preliminary phenotypic properties, plant growth promoting activity and biological control potential, 10 isolates were randomly selected and 
Table 1. Preliminary phenotypic grouping and identification of endophytic bacterial isolates by partial sequencing of 16s rRNA

\begin{tabular}{|c|c|c|c|c|c|c|c|}
\hline Strains & $\begin{array}{l}\text { Gram } \\
\text { reaction }\end{array}$ & Oxidase & $\begin{array}{l}\text { Catalase } \\
\text { production }\end{array}$ & $\begin{array}{c}\text { Fluorescent pigment } \\
\text { production }\end{array}$ & $\begin{array}{l}\text { 16s rRNA sequence } \\
\quad\left(5^{\prime} \rightarrow 3^{\prime}\right)\end{array}$ & $\%$ similarity & $\begin{array}{c}\text { GenBank } \\
\text { accession no. }\end{array}$ \\
\hline $\mathrm{Pb} 1$ & - & - & + & - & $1-1338$ & $99 \%$ with Pantoea brenneri & KU693267 \\
\hline $\mathrm{Pb} 3$ & - & - & + & - & $45-1431 \mathrm{bp}$ & $\begin{array}{l}100 \% \text { with Pseudomonas } \\
\text { protegens }\end{array}$ & KU693268 \\
\hline $\mathrm{Pb} 24$ & - & + & + & + & $51-1432 b p$ & $\begin{array}{l}100 \% \text { with Pseudomonas } \\
\text { protegens }\end{array}$ & KU693269 \\
\hline $\mathrm{Pb} 71$ & - & + & + & + & $46-1432 \mathrm{bp}$ & $\begin{array}{l}100 \% \text { with Pseudomonas } \\
\text { protegens }\end{array}$ & KU693270 \\
\hline $\mathrm{Pb} 78$ & - & + & + & + & $47-1431 \mathrm{bp}$ & $\begin{array}{l}100 \% \text { with Pseudomonas } \\
\text { protegens }\end{array}$ & KU693271 \\
\hline $\mathrm{Sm} 25$ & - & - & + & - & $43-1418 b p$ & $\begin{array}{l}99 \% \text { with Stenotrophomonas } \\
\text { maltophilia }\end{array}$ & KU693275 \\
\hline Sm97 & - & - & + & - & $43-1419 b p$ & $\begin{array}{l}99 \% \text { with Stenotrophomonas } \\
\text { maltophilia }\end{array}$ & KU693276 \\
\hline $\mathrm{Ba} 66$ & + & - & + & - & $4-1306 \mathrm{bp}$ & $99 \%$ with Bacillus anthracis & KU693274 \\
\hline Bp108 & + & + & + & - & $23-1390$ & $99 \%$ with Bacillus pumilus & KU693273 \\
\hline Sp15 & - & - & + & - & $63-1422$ & $100 \%$ with Serratia plymuthica & KU693272 \\
\hline
\end{tabular}

further characterized by comparative sequence analysis of the 16S rRNA gene generated by PCR. Based on results obtained, nucleotide sequencing of the nearly full length of the 16S rRNA gene from all isolates possessed 99-100\% similarity with a species already described in the GenBank database (Table 1).

Sequence analysis indicates that strains $\mathrm{Pb} 3, \mathrm{~Pb} 24, \mathrm{~Pb} 71$ and $\mathrm{Pb} 78$ have $100 \%$ homology with Pseudomonas protegens $\mathrm{CHA}^{\mathrm{T}}$. The nucleotide sequences of $16 \mathrm{~S}$ rRNA gene revealed that Sm25 and Sm97 strains had 100\% and $99 \%$ similarity to Stenotrophomonas maltophilia IAM12423 $3^{\mathrm{T}}$, respectively. Strains Ba66 and Bp108 showed
99\% 16S rRNA sequence similarity to Bacillus anthracis ATCC $14578^{\mathrm{T}}$ and B. pumilus ATCC $7061^{\mathrm{T}}$, respectively. As well as strains Sp15 and Pb1 showed 100\% and 99\% similarity to Serratia plymuthica DSM $4540^{\mathrm{T}}$ and Pantoea brenneri LMG5343 ${ }^{\mathrm{T}}$, respectively. A Phylogenetic tree was constructed using the partial 16S rRNA sequences of the putative endophytic bacterial isolates and representative bacterial type strains of related taxa generated by neighborjoining method is presented in Fig. 1.

In vitro biocontrol activity of endophytic bacteria. Strains were tested in vitro for their ability to inhibit the

Table 2. Plant growth potential properties of 10 bacterial strains isolated from wild Pistachio trees

\begin{tabular}{|c|c|c|c|c|c|c|}
\hline Strains & $\begin{array}{c}\text { Phosphate } \\
\text { solubilization }\end{array}$ & $\begin{array}{l}\text { Siderophore } \\
\text { production }\end{array}$ & $\begin{array}{c}\text { Nitrogen } \\
\text { fixation activity }\end{array}$ & $\begin{array}{l}\text { Protease } \\
\text { production }\end{array}$ & $\begin{array}{c}\mathrm{HCN} \\
\text { production }\end{array}$ & $\begin{array}{l}\text { Root weight of } \\
\text { carrot }(\mathrm{mg})^{\mathrm{a}}\end{array}$ \\
\hline $\mathrm{Pb} 1$ & + & + & + & - & - & $10.5^{\mathrm{d}}$ \\
\hline $\mathrm{Pb} 3$ & - & - & - & - & - & $26^{a}$ \\
\hline $\mathrm{Pb} 24$ & + & - & + & + & - & $20.1^{\mathrm{bc}}$ \\
\hline $\mathrm{Pb} 71$ & + & + & + & - & - & $21.5^{\mathrm{b}}$ \\
\hline $\mathrm{Pb} 78$ & + & + & + & + & - & $7.5^{\mathrm{d}}$ \\
\hline $\mathrm{Sm} 25$ & + & - & - & + & - & $18.5^{\mathrm{bc}}$ \\
\hline Sm97 & + & - & - & - & - & $18.5^{\mathrm{bc}}$ \\
\hline Sp15 & - & + & + & - & - & $17.1^{\mathrm{c}}$ \\
\hline Ba66 & - & - & - & + & + & $7^{\mathrm{d}}$ \\
\hline Bp108 & + & + & - & - & - & $16.7^{\mathrm{c}}$ \\
\hline Control & & & & & & $6.7^{\mathrm{d}}$ \\
\hline
\end{tabular}

${ }^{a}$ Means with the same letter are not significantly different at $1 \%$ level. 


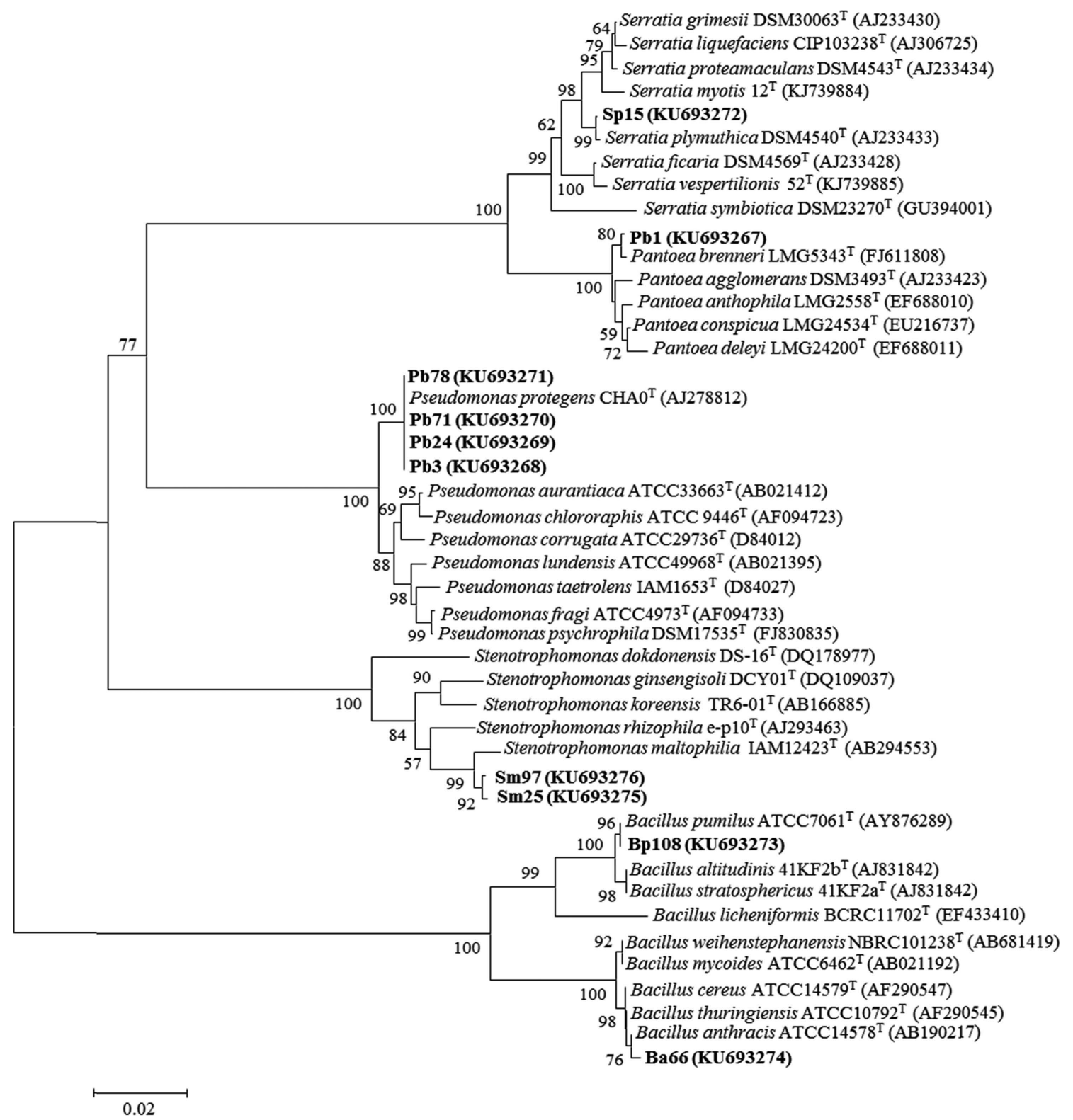

Fig. 1. Phylogenetic tree of partial 16S rRNA sequences of bacterial strains isolated from wild Pistachio trees along with the sequences from selected references strains. The analysis was conducted with PAUP v. 4.0b10 using neighbor-joining method.

growth of bacterial plant pathogens, $P$. syringae pv. syringae Pss 20 and $P$. tolaasii Pt18. All strains suppressed the growth of the pathogens, indicated by different size of inhibition zone. The inhibition zone produced by bacterial endophytes ranged between 3 and $36 \mathrm{~mm}$ in radius (Fig. 2). Amongst the isolates tested $\mathrm{Pb} 78$ had the highest inhibition effect on the pathogens. Sp15 had the lowest inhibition effect against both pathogens (Fig. 3).

Plant growth promotion potential. Biosynthesis of phytohormones, indole acetic acid (IAA) and gibberellic acid (GA) were calculated for each isolate. About $40 \%$ of isolates were able to produce IAA at the range of 2.7-57.6 $\mu \mathrm{g} / \mathrm{ml}$. Sp15 strain with $57.6 \mu \mathrm{g} / \mathrm{ml}$ produced the highest amount of IAA among strains tested. According to results obtained, $31 \%$ of isolates had the ability to produce GA at the range of $12.7-21.8 \mu \mathrm{g} / \mathrm{ml}$. The $\mathrm{Pb} 71$ strain was able to produce the highest amount of GA among strains studied (Fig. 4). Approximately $35 \%$ of strains were able to grow on nitrogen free medium, indicating diazotroph capability and had the ability to produce protease. Approximately $30 \%$ of strains formed a clear halo zone around the spot inoculation of Pikovskaya's medium, indicating phosphate solubilization activity. Furthermore $30 \%$ of strains were 

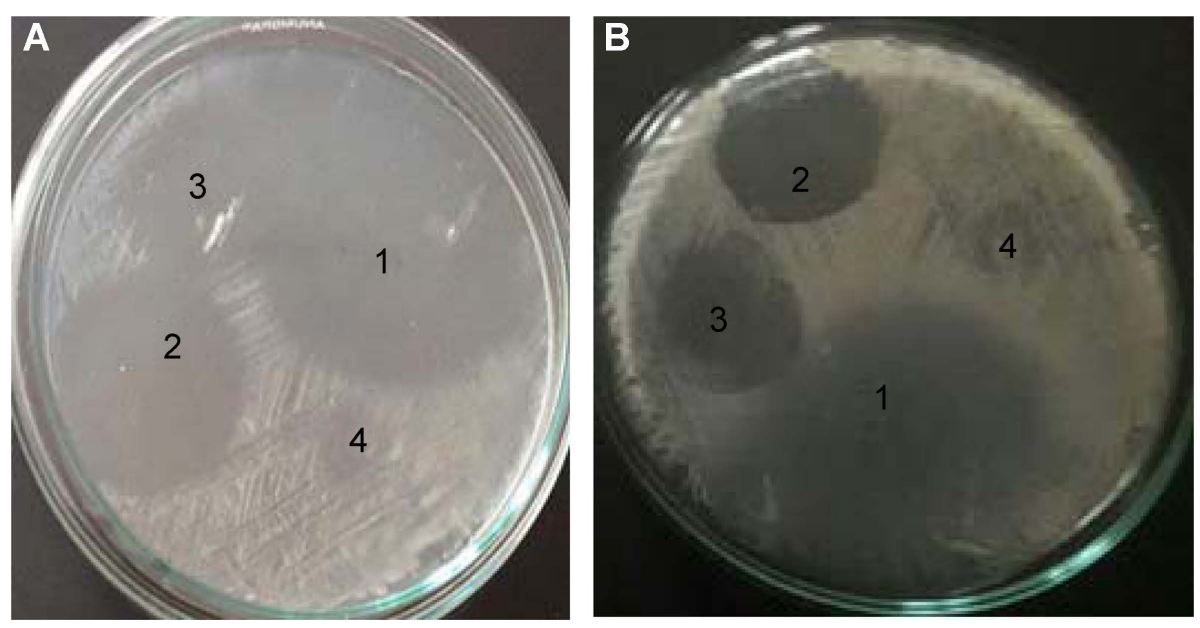

Fig. 2. Diameter of the inhibition zone produced by endophytic bacterial strains against. (A) Pseudomonas syringae pv. syringae Pss20, and (B) Pseudomonas tolaasii Pt18. 1: Pb78, 2: Bp108, 3: Ba66 and 4: Pb1 strains.

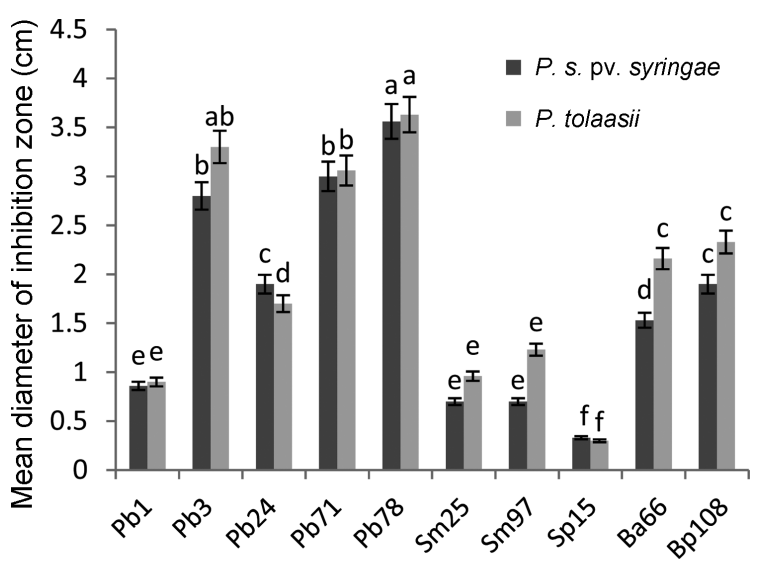

Endophytic bacterial strain

Fig. 3. Antagonistic activity of endophytic bacterial strains against bacterial plant pathogens, $P$. s. pv. syringae Pss20 and $P$. tolaasii Pt18 under in vitro condition. Data represents the mean of three replicates \pm SE. Data were analyzed by ANOVA and post hoc Duncan test $<0.05$. Means with the same letter are not significantly different.

able to produce siderophore on CAS medium. Amongst all the strains tested only strain Ba66 was positive for $\mathrm{HCN}$ production. Results of plant growth promotion properties of selected strains are presented in Table 2.

All bacterial strains except $\mathrm{Pb} 78$ and $\mathrm{Ba} 66$ strains promoted root formation when inoculated into media containing carrot slices. The Pb3 strain had the highest effect and significantly enhanced biomass of the root compared with non-inoculated treatment.

\section{Discussion}

The culturable endophytic bacterial population of healthy looking stems and leaves of wild Pistachio trees were as-

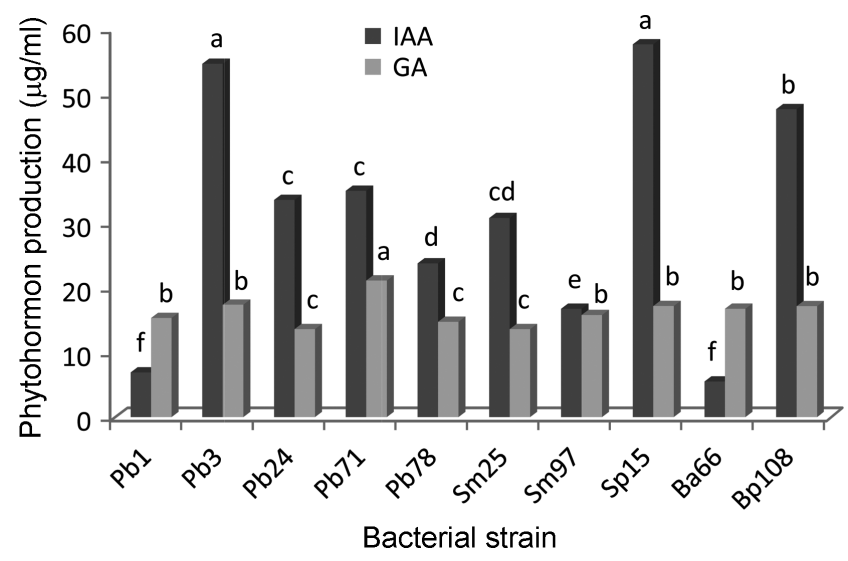

Fig. 4. Indole acetic acid and Gibberellic acid production by endophytic bacterial strains. Each value represents the mean of three replicates. Means with the same letter are not significantly different at $1 \%$ probability level.

sessed. The results of the effectiveness of the surface sterilization method showed no microbial growth in control plates, indicating that isolates are endophyte. According to data obtained in this study, endophytic bacterial populationsofwildPistachiowere constituted by both gram-negative and -positive bacteria. Selected strains phenotypically and by sequencing of $16 \mathrm{~S}$ rRNA gene were identified as a member of Pseudomonas, Stenotrophomonas, Serratia, Pantoea and Bacillus genus. However, the assignment of bacterial isolates to a given species requires further phenotypic and molecular characterization. Based on results obtained in the present study four strains isolated had similarity to $P$. protegens, two strains were related to $S$. maltophilia, two strains had high similarity to $B$. anthracis and $B$. pumilus, and two strains were related to $S$. plymuthica and $P$. brenneri. Several reports concerning the presence of $P$. protegens strains and bacteria belonging to Bacillus, Serra- 
tia, Pantoea and Stenotrophomonas genus inside the various parts of other plants as endophytic bacteria exist (Berg et al., 2005; Hardoim et al., 2012, Ren et al., 2013; Saidi et al., 2013). All strains identified in this study were related to previously identified species with plant growth promotion or biocontrol activity (Rosenblueth and Martinez-Romero, 2006).

Some of the isolated endophytes from wild pistachio such as Bp3, Sp15 and Bp108 synthesized a high amount of the phytohormone IAA which is involved in plant root and stem growth regulation. Previous reports indicated that many endophytic bacteria including, Pseudomonas, Serratia and Bacillus are able to synthesize IAA (Liu et al., 2010; Sgroy et al., 2009). B. pumilus B3 isolated from the root of European alder produced high amounts of IAA (Gutierrez Manero et al., 1996). Koo and Cho (2009) showed that Serratia plymuthica SY5 isolated from heavy metal contaminated soil had capacity for IAA production and root growth potential. A previous report also indicated that $P$. protegens strains can produce IAA and stimulate plant growth (Bensidhoum et al., 2016). In our study there was no direct relationship between the IAA producing ability of strains and root growth promoting effects. Perhaps these strains triggered growth promoting activity by more than one mechanism or can be plant specific. The same results have been reported for other endophytic bacteria-plant relationship (Khan and Doty, 2009).

In this research all ten selected strains were able to produce different amounts of phytohormone, GA. Statistically, $\mathrm{Pb} 71$ synthesized higher amounts of GA followed by $\mathrm{Pb} 3$, Sp15, Bp108 and Ba66. Both Pb71 and Pb3 with the highest GA production also had the greatest influence on root formation of carrot slices under in vitro condition. This phytohormone has a role in plant growth, promotes primary and lateral root elongation, and increases yield (Bottini et al., 2004). It is well documented that bacteria belonging to fluorescent Pseudomonas, Bacillus and rhizobia known to improve plant growth has the ability to produce gibberellins. The majority of these bacteria have been isolated from rhizosphere or the root of associated plants (Vacheron et al., 2013). A previous report indicated that B. pumilus isolated from the rhizosphere had the growth promoting effect of red pepper and this effect originated from GA production (Joo et al., 2004).

Nitrogen fixation is well studied in the rhizobial bacteria symbiotic with plant hosts. Moreover, some endophytic bacteria with nitrogen-fixing ability have been isolated from trees like poplar and willow (Doty et al., 2009; Ulrich et al., 2008). Several strains investigated in this study and belonging to Pseudomonas, Pantoea and Serratia genus can grow well on nitrogen-free medium, supporting the hypothesis that these strains might be of diazotrophic nature. However, further studies such as looking for the presence of $\mathrm{N} 2$ fixation gene or acetylene reduction assay are needed to confirm the contribution of these endophytes to the nitrogen input if wild Pistachio trees grow well in forest soil. Previous reports have indicated that bacterial endophytes like Pantoea, Pseudomonas and Serratia had potential nitrogen fixation ability of other plants (Loiret et al., 2004). Deng et al. (2011) reported S. plymuthica and Pseudomonas fluorescens strains as endophytic bacteria associated with the root nodules of plant host which could increase nodule number and average nodule weight under nitrogenfree conditions.

In the present study, it was observed that several strains identified, such as $\mathrm{Pb} 1, \mathrm{~Pb} 71, \mathrm{~Pb} 78, \mathrm{Sp} 15$ and $\mathrm{Bp} 108$ were able to produce siderophore, solubilize phosphate or both. Siderophore produced by bacteria can promote plant growth through enhanced direct iron availability to plants under iron deficient conditions or by inhibiting the availability of iron to plant pathogens (Ahmad et al., 2008). In addition, phosphorus is one of the major macronutrients necessary for biological growth and development of plants. Phosphate solubilizing bacteria are capable of solubilizing the insoluble phosphate, increase soil quality and plant growth (Rodriguez and Fraga, 1999). It is well documented that such properties have a role in plant growth promotion and some authors have previously reported these capabilities in other strains belonging to the same genus identified in this work. Bensidhoum et al. (2016) reported P. protegens strains with plant growth promotion and their activity was associated with the production of siderophores and the solubilization of phosphate. S. plymuthica Sp15 with the ability for IAA and siderophore production significantly increased the root weight of carrot. Similarly, Serratia sp. SY5 strain with the same capacity has been reported (Koo and Cho, 2009). Earlier research reported B. pumilus S1r1 strains with their ability to solubilize phosphate, with the main mechanism of plant growth promotion being nitrogen fixation activity (Kuan et al., 2016).

Among strains tested, only Ba66 with high similarity to $B$. anthracis was able to produce $\mathrm{HCN}$. Although $B$. anthracis is considered an obligate pathogen of humans and animals, recent studies show that some strains promote plant growth (Ganz et al., 2014). Regardless of plant growth promotion or biocontrol potential of $B$. anthracis strains, this species is usually classified as a biohazardous agent within risk group 3 indicating high potential human disease risk (Advisory Committee on Dangerous Pathogens,, 2013). The results of our study showed this strain had no effect on root forma- 
tion. Compared to this result the previous report indicated that strains with this ability had an inhibition effect on root formation of plants (Schippers et al., 1990). There are conflicting views about the role of bacteria in plant growth and the manners in which HCN production are involved. Some deleterious bacteria reduce plant yields through $\mathrm{HCN}$ production (Bakker and Schippers, 1987). However, HCN production is a biological control mechanism by bacterial antagonists (Kumar et al., 2012). Some plant growth promoting bacteria produce such secondary metabolites which are recognized as biological control agents against fungal and bacterial plant pathogens. Also, HCN can indirectly increase availability of phosphorus and iron to plants, resulting in increased plant growth promotion activity (Rijavec and Lapanje, 2016).

This study has demonstrated the high antagonistic potential of strains $\mathrm{Pb} 71, \mathrm{~Pb} 78$ and $\mathrm{Pb} 3$ followed by $\mathrm{Ba} 66$, Bp108 and $\mathrm{Pb} 24$ against both bacterial pathogens tested in this work under in vitro condition. Therefore, these strains had the potential to be used as biological control agents. Strains $\mathrm{Pb} 78$ and $\mathrm{Pb} 71$ with their ability to produce siderophore and protease had the highest inhibition effects against pathogens. Surprisingly, $\mathrm{Pb} 3$ strain with high similarity to $P$. protegens were negative for all traits but had high biocontrol activity in vitro suggesting that this strain is using other mechanisms against pathogens. In addition to the siderophore, protease and $\mathrm{HCN}$ production, the observed antagonistic potential of the strains is probably due to production of antibiotic compounds. Previous reports have indicated that $P$. protegens strains can produce antimicrobial compounds which are active against various plant pathogens (Loper et al., 2007; Ramette et al., 2011; Wang et al., 2015).

Strain Ba66 with high similarity to $B$. anthracis and positive in protease and HCN production and Bp108 with similarity to B. pumilus and able to produce siderophore, had high inhibition effects of both pathogens. Several reports examining the ability of $B$. pumilus strains in suppressing plant pathogens exist (Ren et al., 2013). Amaresan et al (2012) reported B. pumilus strain capable of producing siderophore with high biocontrol activity against several plant pathogens. Amongst the two strains identified in the present study similar to $S$. maltophilia only $\operatorname{Sm} 25$ strain was able to produce protease, but both strains did not have significant inhibitory effects on the growth of bacterial pathogens under in vitro condition. Previous research suggest that strains of $S$. maltophilia which have high proteolytic potential and antimicrobial-associated genes, contribute to the biocontrol activity of this bacterium (Ryan et al., 2009; Zho et al., 2012).
Because forest trees have different biological properties compared to agricultural plants they can provide specific ecological circumstances. Additionally, endophytic bacteria with the positive effects on the host trees can be useful for forestry practices to increase yield and improve environmental quality. This initial study revealed the existence of several bacterial species living as an endophyte in various parts of the wild Pistachio tree. Some works show that season has strong effects on the endophyte population structure in tree species (Shen and Fulthorpe, 2015). Therefore to have a correct view in regards the diversity of endophytic bacteria and possible plant-endophyte interactions it is necessary to study the endophytic population through different seasons. In our study, some of the isolates produced phytohormone IAA and GA in different amounts. The microbial synthesis of plant growth regulators is an important factor that could influence plant growth in harsh environments.

In conclusion, this study demonstrated the occurrence and diversity of culturable bacterial endophytes in wild Pistachio trees. Despite the economic importance and geographical distribution of wild Pistachio trees, no studies are found on endophytic bacteria associated with this plant. According to results obtained in this study, strains $\mathrm{Pb} 3, \mathrm{~Pb} 71$ and $\mathrm{Bp} 108$ with high similarity to P. protegens and B. pumilus respectively, have the potential to be used as biological control and/or plant growth promoting agents. Strain Pb78 had high biological control potential and Sp15 is a suitable candidate to use as plant growth promoting agent. To our knowledge this is the first report which is concerned with the isolation of bacterial endophyte from this plant host. The existence of such microorganisms suggests that they can be utilized in future application such as controlling plant diseases or enhancing plant growth. However further in vivo studies and investigation under natural environmental conditions are needed to confirm this hypothesis.

\section{Acknowledgments}

This research work was supported by University of Kurdistan, Iran.

\section{References}

Anonymous. 2013. The Approved List of biological agents. 3rd ed. Health and Safety Executive, UK. URL http://www.hse. gov.uk/pubns/misc208.pdf/.

Ahmad, F., Ahmad, I. and Khan, M. S. 2008. Screening of freeliving rhizospheric bacteria for their multiple plant growth 
promoting activities. Microbiol. Res. 163:173-181.

Alstrom, S. and Burns, R. G. 1989. Cyanide production by rhizobacteria as a possible mechanism of plant growth inhibition. Biol. Fertil. Soil 7:232-238.

Aliye, N., Fininsa, C. and Hiskias, Y. 2008. Evaluation of rhizosphere bacterial antagonists for their potential to bioprotect potato (Solanum tuberosum) against bacterial wilt (Ralstonia solanacearum). Biol. Control 47:282-288.

Amaresan, N., Jayakumar, V., Kumar, K. and Thajudin, N. 2012. Isolation and characterization of plant growth promoting endophytic bacteria and their effect on tomato (Lycopersicon esculentum) and chilli (Capsicum annuum) seedling growth. Ann. Microbiol. 62:805-810.

Anand, R., Grayston, S. and Chanway, C. 2013. $\mathrm{N}_{2}$-Fixation and seedling growth promotion of Lodgepole Pine by endophytic Paenibacillus polymyxa. Microb. Ecol. 66:369-374.

Bacon, C. W. and Hinton, D. M. 2006. Bacterial endophytes: the endophytic niche, its occupants, and its utility. In: PlantAssociated Bacteria ed. by S. S. Gnanamanickam, pp. 155194. Springer, Dordrecht.

Bakker, A. W. and Schippers, B. 1987. Microbial cyanide production in the rhizosphere in relation to potato yield reduction and Pseudomonas spp.-mediated plant growth-stimulation. Soil. Biol. Biochem. 19:451-457.

Bensidhoum, L., Nabti, E., Tabli, N., Kupferschmied, P., Weiss, A., Rothballer, M., Schmid, M., Keel, C. and Hartmann, A. 2016. Heavy metal tolerant Pseudomonas protegens isolates from agricultural well water in northeastern Algeria with growth promoting, insecticidal and antifungal activities. Eur. J. Soil. Biol. 75:38-46.

Berg, G., Krechel, A., Ditz, M., Sikora, R. A., Ulrich, A. and Hallmann, J. 2005. Endophytic and ectophytic potato-associated bacterial communities differ in structure and antagonistic function against plant pathogenic fungi. FEMS Microbiol. Ecol. 51:215-229.

Bottini, R., Cassan, F. and Piccoli, P. 2004. Gibberellin production by bacteria and its involvement in plant growth promotion and yield increase. Appl. Microbiol. Biotechnol. 65:497503.

Chebotar, V. K., Malfanova, N. V., Shcherbakov, A. V., Ahtemova, G. A., Borisov, A. Y., Lugtenberg, B. and Tikhonovich, I. A. 2015. Endophytic bacteria in microbial preparations that improve plant development (review). Appl. Biochem. Microbiol. 51:271-277.

Compant, S., Duffy, B., Nowak, J., Clement, C. and Barka, E. A. 2005. Use of plant growth-promoting bacteria for biocontrol of plant diseases: principles, mechanisms of action, and future prospects. Appl. Environ. Microbiol. 71:4951-4959.

Deng, Z. S., Zhao, L. F., Kong, Z. Y., Yang, W. Q., Lindström, K., Wang, E. T. and Wei, G. H. 2011. Diversity of endophytic bacteria within nodules of the Sphaerophysa salsula in different regions of Loess Plateau in China. FEMS Microbiol. Ecol. 76:463-475.

Döbereiner, J., Baldani, V. and Baldani, J. 1995. Como isolar e identificar bacterias diazotroficas de plantas nao-leguminosas. EMBRAPA-SPI, Brasília, Brazil, EMBRAPA-CNPAB, Itagui, Colombia. 60 pp.

Doty, S. L., Oakley, B., Xin, G., Kang, J. W., Singleton, G., Khan, Z., Vajzovic, A. and Staley, J. T. 2009. Diazotrophic endophytes of native black cottonwood and willow. Symbiosis 47:23-33.

Ganz, H. H., Turner, W. C., Brodie, E. L., Kusters, M., Shi, Y., Sibanda, H., Torok, T. and Getz, W. M. 2014. Interactions between Bacillus anthracis and plants may promote Anthrax transmission. PLoS Negl. Trop. Dis. 8:e2903.

Gutierrez Manero, F. J., Acero, N., Lucas, J. A. and Probanza, A. 1996. The influence of native rhizobacteria on European alder (Alnus glutinosa (L.) Gaertn.) growth. Plant Soil 182:67-74.

Hall, T. A. 1999. BioEdit: a user-friendly biological sequence aligment editor and analysis program for windows 95-98/NT. Nucl. Acids. Symp. Ser. 41:95-98.

Hardoim, P. R., Hardoim, C. C. P., van Overbeek, L. S. and van Elsas, J. D. 2012. Dynamics of seed-borne rice endophytes on early plant growth stages. PLoS One 7:e30438.

Holbrook, A. A., Edge, W. J. W. and Bailey, P. 1961. Spectrophotometric method for determination of Gibberellic acid. Adv. Chem. 28:159-167.

Joo, G. J., Kim, Y. M., Lee, I. J., Song, K. S. and Rhee, I. K. 2004. Growth promotion of red pepper plug seedlings and the production of gibberellins by Bacillus cereus, Bacillus macrolides and Bacillus pumilus. Biotechnol. Lett. 26:487-491.

Khan, Z. and Doty, S. L. 2009. Characterization of bacterial endophytes of sweet potato plants. Plant Soil 322:197-207.

Kheirandish, Z. and Harighi, B. 2015. Evaluation of bacterial antagonists of Ralstonia solanacearum, causal agent of bacterial wilt of potato. Biol. Control 86:14-19.

Koo, S. Y. and Cho, K. S. 2009. Isolation and characterization of a plant growth-promoting rhizobacterium, Serratia sp. SY5. J. Microbiol. Biotech. 19:1431-1438.

Kuan, K. B., Othman, R., Rahim, K. A. and Shamsuddin, Z. H. 2016. Inoculation to enhance vegetative growth, Nitrogen fixation and Nitrogen remobilization of Maize under greenhouse conditions. PLoS One 11:0152478.

Kumar, P., Dubey, R. C. and Maheshwari, D. K. 2012. Bacillus strains isolated from rhizosphere showed plant growth promoting and antagonistic activity against phytopathogens. Microbiol. Res. 167:493-499.

Liu, X., Jia, J., Atkinson, S., Camara, M., Gao, K., Li, H. and Cao, J. 2010. Biocontrol potential of an endophytic Serratia sp. G3 and its mode of action. World J. Microbiol. Biotechnol. 26:1465-1471.

Loiret, F. G., Ortega, E., Kleiner, D., Ortega-Rodes, P., Rodes, R. and Dong, Z. 2004. A putative new endophytic nitrogenfixing bacterium Pantoea sp. from sugarcane. J. Appl. Microbiol. 97:504-511.

Loper, J. E., Kobayashi, D. Y. and Paulsen, I. T. 2007. The genomic sequence of Pseudomonas fluorescens Pf-5: insights into biological control. Phytopathology 97:233-238. 
Madmony, A., Chernin, L., Pleban, S., Peleg, E. and Riov, J. 2005. Enterobacter cloacae, an obligatory endophyte of pollen grains of mediterranean pines. Folia Microbiol. (Praha) 50:209-216.

Mozaffarian, V. 1998. A dictionary of Iranian plant names. Farhang Moaser, Tehran, Iran. 365 pp.

Naik, P. R., Raman, G., Narayanan, K. B. and Sakthivel, N. 2008. Assessment of genetic and functional diversity of phosphate solubilizing fluorescent pseudomonads isolated from rhizospheric soil. BMC Microbiol. 8:230.

Pirttila, A. M. and Frank, A. C. 2011. Endophytes of forest trees, biology and application. Springer, The Netherlands. 319 pp.

Rahman, A., Sitepu, I. R., Tang, S. Y. and Hashidoko, Y. 2010. Salkowski's reagent test as a primary screening index for functionalities of Rhizobacteria isolated from wild dipterocarp saplings growing naturally on medium-strongly acidic tropical peat soil. Biosci. Biotechnol. Biochem. 74:2202-2208.

Ramette, A., Frapolli, M., Fischer-Le Saux, M., Gruffaz, C., Meyer, J. M., Defago, G., Sutra, L. and Moenne Loccoz, Y. 2011. Pseudomonas protegens sp. nov., widespread plantprotecting bacteria producing the biocontrol compounds 2,4-diacetylphloroglucinol and pyoluteorin. Syst. Appl. Microbiol. 34:180-188.

Reinhold-Hurek, B. and Hurek, T. 2011. Living inside plants: bacterial endophytes. Curr. Opin. Plant Biol. 14:435-443.

Ren, J. H., Li, H., Wang, Y. F., Ye, J. R., Yan, A. Q. and Wu, X. Q. 2013. Biocontrol potential of an endophytic Bacillus pumilus JK-SX001 against poplar canker. Biol. Control 67:421-430.

Rijavec, T. and Lapanje, A. 2016. Hydrogen cyanide in the rhizosphere: not suppressing plant pathogens, but rather regulating availability of phosphate. Front. Microbiol. 7:1785.

Rodriguez, H. and Fraga, R. 1999. Phosphate solubilizing bacteria and their role in plant growth promotion. Biotechnol. Adv. 17:319-339.

Rosenblueth, M. and Martinez-Romero, E. 2006. Bacterial endophytes and their interactions with hosts. Mol. Plant-Microbe Interact. 19:827-837.

Ryan, R. P., Monchy, S., Cardinale, M., Taghavi, S., Crossman, L., Avison, M. B., Berg, G., van der Lelie, D. and Dow, J. M. 2009. The versatility and adaptation of bacteria from the genus Stenotrophomonas. Nat. Rev. Microbiol. 7:514-525.

Saidi, S., Chebil, S., Gtari, M. and Mhamdi, R. 2013. Characterization of root-nodule bacteria isolated from Vicia faba and selection of plant growth promoting isolates. World J. Microbiol. Biotech. 29:1099-1106.

Schaad, N. W., Jones, J. B. and Chun, W. 2001. Laboratory guide for identification of plant pathogenic Bacteria. 3rd ed. APS press, St. Paul, MN, USA. 373 pp.

Schippers, B., Bakker, A. W., Bakker, A. H. M. and Van Peer, R. 1990. Beneficial and deleterious effects of HCN-producing pseudomonads on rhizosphere interactions. Plant Soil 129:7583.

Schwyn, B. and Neilands, J. B. 1987. Universal chemical assay for the detection and determination of siderophores. Anal. Biochem. 160:47-56.

Sgroy, V., Cassan, F., Masciarelli, O., Del Papa, M. F., Lagares, A. and Luna, V. 2009. Isolation and characterization of endophytic plant growth promoting (PGPB) or stress homeostasisregulating (PSHB) bacteria associated to the halophyte Prosopis strombulifera. Appl. Microbiol. Biotech. 85:371-381.

Shen, S. Y. and Fulthorpe, R. 2015. Seasonal variation of bacterial endophytes in urban trees. Front. Microbiol. 6:427.

Swofford, D. L. 2003. PAUP* 4.0b10: phylogenetic analysis using parsimony (*and other methods). Sinauer Associates, Sunderland, MA, USA.

Taghavi, S., Garafola, C., Monchy, S., Newman, L., Hoffman, A., Weyens, N., Barac, T., Vangronsveld, J. and van der Lelie, D. 2009. Genome survey and characterization of endophytic bacteria exhibiting a beneficial effect on growth and development of poplar trees. Appl. Environ. Microbiol. 75:748-757.

Ulrich, K., Ulrich, A. and Ewald, D. 2007. Diversity of endophytic bacterial communities in poplar grown under field conditions. FEMS Microbiol. Ecol. 63:169-180.

Ulrich, K., Ulrich, A. and Ewald, D. 2008. Paenibacillus- a predominant endophytic bacterium colonizing tissue cultures of woody plants. Plant Cell Tiss. Organ Cult. 93:347-351.

Vacheron, J., Desbrosses, G., Bouffaud, M. L., Touraine, B., Moenne-Loccoz, Y., Muller, D., Legendre, L., WisniewskiDye, F. and Prigent-Combaret, C. 2013. Plant growthpromoting rhizobacteria and root system functioning. Front. Plant Sci. 4:356.

Wang, X., Mavrodi, D. V., Ke, L., Mavrodi, O. V., Yang, M., Thomashow, L. S., Zheng, N., Weller, D. M. and Zhang, J. 2015. Biocontrol and plant growth-promoting activity of rhizobacteria from Chinese fields with contaminated soils. Microb. Biotechnol. 8:404-418.

Weisburg, W. G., Barns, S. M., Pelletier, D. A. and Lane, D. J. 1991. 16S ribosomal DNA amplification for phylogenetic study. J. Bacteriol. 173:697-703.

Zho, B., Liu, H., Tian, W. X., Fan, X. Y., Li, B., Zhou, X. P., Jin, G. L. and Xie, G. L. 2012. Genome sequence of Stenotrophomonas maltophilia RR-10, isolated as an endophyte from rice root. J. Bacteriol. 194:1280-1281. 